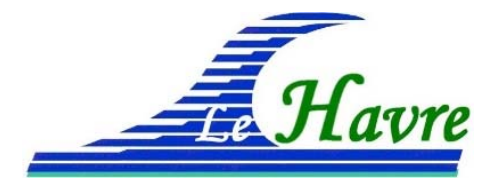

XVI èmes Journées Nationales Génie Côtier - Génie Civil

Le Havre, 2020

DOI:10.5150/jngcgc.2020.016 C Editions Paralia CFL

disponible en ligne - http://www.paralia.fr - available online

\title{
Numerical study of longshore variability in run-up along an idealized embayed beach
}

\author{
Jonas PINAULT ${ }^{1}$, Denis MORICHON ${ }^{1}$, Stéphane ABADIE ${ }^{1}$, Volker ROEBER ${ }^{1}$ \\ 1. Université de Pau et des Pays de l'Adour, E2S UPPA, SIAME, Chaire HPC-Waves, \\ Anglet, France. \\ jonas.pinault@univ-pau.fr ; denis.morichon@univ-pau.fr ; \\ stephane.abadie@univ-pau.fr ; volker.roeber@univ-pau.fr
}

\begin{abstract}
:
It is of common knowledge that energetic swell events bare the potential of threatening people and infrastructure in densely inhabited coastal regions. Parametric formulations, based on various data-sets, have been commonly employed to easily estimate wave runup based on offshore conditions and beach parameters. These formulations are however mostly based on open beaches data-sets and their accuracy in complex $3 \mathrm{D}$ configuration such as an embayed beach is thus questionable.

In this numerical study, a phase-resolving Boussinesq-type model is used to investigate the longshore distribution of wave run-up in an idealized embayed beach from an oblique wave approach in order to isolate the sole effects of the geologically constrained configuration. The numerical model accounts for all major physical processes including refraction, diffraction, reflection, shoaling, breaking. Different scenarios are considered from moderately to extremely energetic incident wave conditions and bay orientations. The run-up is found to vary significantly alongshore for the majority of the tested scenarios (run-up elevation can vary by a factor 3 ). A spectral analysis of the water levels shows that this variability is tightly connected to the infragravity waves $(0.002$ to $0.04 \mathrm{~Hz}$ ). The relative contribution of those long waves to the total run-up varies along the beach displaying hotspots where wave energy focuses leading to highest run-up values. Those results, obtained for an idealized embayed beach, suggest to further investigation on the role of infragravity waves including the processes of nearshore wave transformation in more realistic embayement conditions in order to improve flooding risk assessment in this particular type of beach.
\end{abstract}

Keywords: Embayed beach, Run-up, Infragravity waves, Boussinesq-type model, Longshore variability.

\section{Introduction}

The total water elevation at the coast is composed of two components: the tide (astronomical and meteorological) and the incident waves - namely the run-up. Usually, wave run-up is divided into a static component, the wave set-up, and a dynamic component, the swash (HOLMAN \& SALLENGER, 1986). The swash, as a time varying 


\section{Thème 1 - Hydrodynamique côtière}

component, can be subdivided into two frequency bands: the incident or short-wave band (usually from 0.04 to $0.25 \mathrm{~Hz}$ ) and a lower frequency band (from 0.002 to $0.04 \mathrm{~Hz}$ ) referring to the infragravity band (IG). The contributions of the spectral swash components mostly depend on the beach state (RUESSINK et al., 1998; RUGGIERO et al., 2004; STOCKDON et al., 2006), given by the Iribarren number $\xi$ (BATTJES, 1974). Infragravity dominated run-up is usually found under dissipative conditions $(\xi<0.3)$ and incident dominated run-up under reflective conditions $(\xi>1.25)$. The run-up has been extensively studied in the past decades. Field studies have focused on the relationships between run-up values, beach characteristics and offshore bulk wave parameters (HOLMAN, 1986; STOCKDON et al., 2006; ...). They were mostly conducted on open beaches and during low to mild energetic conditions. Their application to extreme events and beaches with complex geometries (embayed beaches, rocks, coastal structures...) is thus questionable. Several studies have highlighted these limitations (STOCKDON et al., 2014; POWER et al., 2013; ...).

Despite their common presence around the world, embayed (natural or artificial) beaches are still considered complex environments. They are constrained by headlands, and the hydrodynamics and morphological processes within the bay differ from the open beaches depending on the degree of embaymentisation (FELLOWES et al., 2019). Numerous studies were carried out to better understand the behaviors of these complex environments (CASTELLE \& COCO, 2012; LOUREIRO et al., 2012) but have mostly focused on sediment transport or morphodynamics. The combined effects of refraction-diffraction processes in the lee of headlands have been intensively studied (GODA et al., 1978) to describe wave heights distribution in embayed beaches but less is known about their effects on wave run-up at the coast.

Considering different storm scenarios and a highly idealized embayed beach configuration, this numerical study, based on a Boussinesq-type model, investigates the relative contribution of the incident and infragravity waves on the run-up intensity and variability.

\section{Methodology}

\subsection{Bathymetry}

An idealized bathymetry, comprising a sloping beach constrained between 2 headlands, is used in this study to assess the influence of a semi-enclosed basin on the longshore runup distribution.

The beach cross-shore profile is based on a beach equilibrium profile (DEAN, 1991) given by $z=A\left(D_{50}\right) x^{2 / 3}$, where $\mathrm{A}$ is the sediment scale parameter depending on $\mathrm{D}_{50}$, the median grain diameter (taken equal to $0.3 \mathrm{~mm}$ in our study). It is completed with an $8 \%$ slope above the mean sea level, as the beach state considered is intermediate-reflective. 


\section{XVİ̀mes Journées Nationales Génie Côtier - Génie Civil \\ Le Havre 2020}

Furthermore, the beach is constrained between two headlands and isobaths within the bay are assumed to be curved (see figure 1).

The degree of embaymentisation (related to the length of the headlands compared to the width of the beach) is the main geological feature controlling the hydrodynamics and morphological processes. The embayment morphometric parameter for this study (FELLOWES et al., 2019) is chosen as 1 (length of the headlands being equal to the width of the beach) as it represents an embayed beach with high coastal indentation, and thus exhibiting different behaviors than open beaches. This idealized beach is $1 \mathrm{~km}$ long and the headlands extend to $1 \mathrm{~km}$ offshore from the shoreline. Mean sea level is fixed at $0 \mathrm{~m}$.
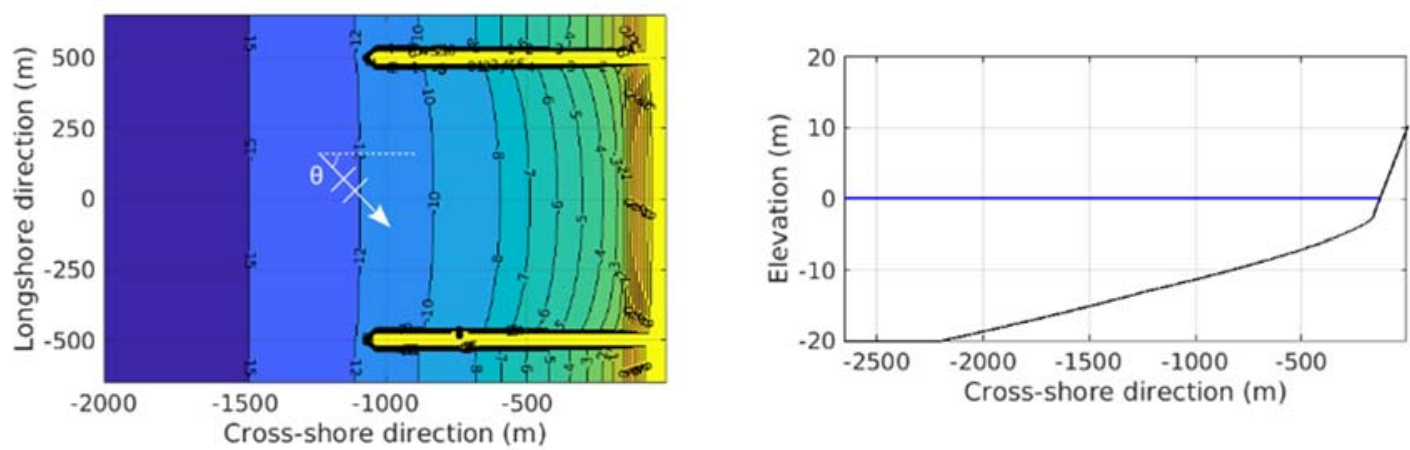

Figure 1. Contour lines of the bathymetry (area of interest) exposed to waves with an angle of incidence $\theta$ (left) and cross-shore transect in the middle of the embayed beach (right). The incident swell direction varies between $0^{\circ}$ and $30^{\circ}$.

\subsection{Wave conditions}

Three different wave conditions are chosen to represent moderate, high, and very energetic swell conditions. Three swell directions are selected to study the influence of the propagation direction of the swell in relation to the orientation of the entrance of the idealized bay. All the scenarios are listed in table 1.

Table 1. Forcing conditions.

\begin{tabular}{lllll}
\hline Event & Case & $H_{s}(\mathrm{~m})$ & $T_{p}(\mathrm{~s})$ & Direction $\left(^{\circ}\right)$ \\
\hline Moderate & $1 ; 4 ; 7$ & 2 & 12 & $0 ; 15 ; 30$ \\
High & $2 ; 5 ; 8$ & 3 & 15 & $0 ; 15 ; 30$ \\
Stormy & $3 ; 6 ; 9$ & 6 & 18 & $0 ; 15 ; 30$ \\
\hline
\end{tabular}

A TMA wave spectrum is used to represent the nearshore incident wave conditions at the offshore boundary (depth $=20 \mathrm{~m})$. 


\section{Thème 1 - Hydrodynamique côtière}

\subsection{Numerical model}

The phase-resolving Boussinesq-type model BOSZ (ROEBER et al., 2010; ROEBER \& CHEUNG, 2012a) is used in this study. The model is based on the set of Boussinesq equations by NWOGU (1993) expressed in conservative form. Phases are randomly assigned to the different frequencies. This weakly non-linear and weakly dispersive model inherently accounts for relevant physical processes in coastal zones including refraction, diffraction, reflection, shoaling, dissipation and breaking. In addition, it allows to simulate the generation and transformation of IG waves, which have been shown to contribute to the run-up (STOCKDON et al., 2006). The model has been validated for the relevant processes in different benchmarks (HORRILLO et al. 2014; LYNETT et al. 2017; ROEBER \& CHEUNG, 2012b).

The inside of the bay is $1 \times 1 \mathrm{~km}$ and the whole computational domain extends $2.5 \mathrm{~km}$ offshore and from 1 to $3 \mathrm{~km}$ on the sides. The resolution is $5 \mathrm{~m}$ in the longshore direction and $2.5 \mathrm{~m}$ in the cross-shore direction. The computation is carried out for one hour including a ramp up time of 15 minutes. The incident wave regime is kept constant during each run. The free surface is recorded at $2 \mathrm{~Hz}$.

\subsection{Post processing}

The run-up time series is extracted at each longshore location by detecting the water elevation in the furthest wet cell with a threshold depth of $10 \mathrm{~cm}$ (STOCKDON et al. 2014).

Wave set-up $<\eta>$ is calculated as the time-averaged water-level elevation at the shoreline. The swash is obtained after subtracting the set-up from the run-up time series. The runup $2 \%$ exceedance value is computed considering the cumulative distribution and its $98^{\text {th }}$ percentile (STOCKDON et al., 2006).

The 45 minutes long signal is separated into segments of 2048 points and is analyzed using a Hanning window with $50 \%$ overlapping. The significant swash height is calculated computing the power spectral density, $\operatorname{PSD}(\mathrm{f})$ :

$S=\sqrt{\sum P S D}(f) d f$

The cut-off period chosen for the separation of the IG and incident band is $2 \mathrm{Tp}$ (SHEREMET et al., 2011). In literature the cut-off frequency is often given as $0.04 \mathrm{~Hz}$ but given the variability of $\mathrm{Tp}$ in the wave conditions a moving cut-off frequency gives a better representation of the infragravity band.

The significant swash height for the incident and the IG bands are computed by using eq. (1) within their specific ranges. 


\section{XVI'èmes Journées Nationales Génie Côtier - Génie Civil \\ Le Havre 2020}

\section{Results}

\subsection{Variability of $R_{2} \%$}

To first assess the magnitude of the run-up variability, $R_{2} \%$ along the beach is computed for different incident wave conditions. The results are presented in table 2 , where the coefficient of variation (CV) is calculated from the standard deviation (std) divided by the mean.

The analysis of std and $\mathrm{CV}$ values of $R_{2} \%$ shows that significant variations are found along the beach, the variability increasing with the wave field obliquity. For the most energetic scenarios (cases $3,6,9$ ) the std ranges from $0.26 \mathrm{~m}$ to $0.62 \mathrm{~m}$ up to $0.87 \mathrm{~m}$. An increase of more than $500 \%$ between the lowest and the highest longshore value of $\mathrm{R}_{2} \%$ is observed in case 7 (moderate climate and $30^{\circ}$ of incidence). For the most energetic case under the highest incidence (case 9), an increase of $212 \%$ is noted.

Due to the shadowing of the headlands, which reduces the area exposed to direct swell, the mean longshore $R_{2} \%$ is smaller in the cases of oblique wave fields regardless of the level of incident energy. For example, mean $R_{2} \%$ goes down from $3.89 \mathrm{~m}$ to $3.59 \mathrm{~m}$ for the stormy case. However, the highest $R_{2} \%$ values occur for oblique conditions. Indeed, the highest $R_{2} \%$ among all the runs is obtained for a $30^{\circ}$ incident peak wave angle. It illustrates the fact that despite being partially sheltered by the headlands (reduction of the mean longshore value) under oblique conditions, the run-up is unevenly distributed, leading to the generation of hotspots where the energy is focused with subsequently higher run-up values.

Table 2. Longshore statistics of $R_{2} \%$ for the different incident wave conditions. Min, mean, max, std respectively refer to minimum, longshore mean and maximum value of $R_{2} \%(m)$, $C V$ the coefficient of variation and $\mathrm{min} /$ max the ratio of the maximum over the minimum longshore value.

\begin{tabular}{cccccccc}
\hline \multirow{2}{*}{ Angle } & \multirow{2}{*}{ Case } & \multicolumn{7}{c}{$R_{2 \%}$} \\
\cline { 2 - 8 } & & min & mean & $\max$ & std & $C V$ & max/min \\
\hline \multirow{3}{*}{$0^{\circ}$} & 1 & 1,12 & 1,36 & 1,45 & 0,08 & $5,95 \%$ & 1,3 \\
\cline { 2 - 8 } & 2 & 1,88 & 2,2 & 2,39 & 0,13 & $5,95 \%$ & 1,27 \\
\cline { 2 - 8 } & 3 & 3,41 & 3,89 & 4,17 & 0,26 & $6,60 \%$ & 1,22 \\
\hline \multirow{3}{*}{$15^{\circ}$} & 4 & 0,69 & 1,24 & 1,58 & 0,24 & $19,39 \%$ & 2,31 \\
\cline { 2 - 8 } & 5 & 1,45 & 2,14 & 2,68 & 0,33 & $15,29 \%$ & 1,85 \\
\hline \multirow{3}{*}{$30^{\circ}$} & 6 & 2,95 & 3,84 & 4,8 & 0,62 & $27,57 \%$ & 2,94 \\
\cline { 2 - 8 } & 7 & 0,31 & 1,08 & 1,73 & 0,35 & $32,09 \%$ & 5,61 \\
\cline { 2 - 8 } & 8 & 0,87 & 1,82 & 2,84 & 0,5 & $27,57 \%$ & 2,94 \\
\hline & 9 & 2,49 & 3,59 & 5,29 & 0,87 & $24,34 \%$ & 2,12 \\
\hline
\end{tabular}




\section{Thème 1 - Hydrodynamique côtière}

\subsection{Analysis of run-up components}

Water motion close to the shore is controlled by both the short incident waves and IG waves $(0.005-0.04 \mathrm{~Hz})$. In the following, a spectral analysis of the computed swash signal is performed for each scenario to estimate the contribution of each frequency band to the water level variations.

The longshore anomaly (calculated as the difference between the local value and the mean longshore value) of the different run-up components is illustrated on figure 2 in order to understand how the uneven distribution is generated.

The comparison of the anomaly of total $R_{2} \%$ (top panel) with the anomalies of the incident (middle panel) and IG bands (lower panel) shows that the anomaly in the run-up is strongly related to the distribution of the IG swash. Indeed, the same trend and the same orders of magnitude (more than $1.5 \mathrm{~m}$ for the most energetic case) are observed. On the contrary, the incident band shows very little deviation, with a maximum anomaly of less than $0.5 \mathrm{~m}$.

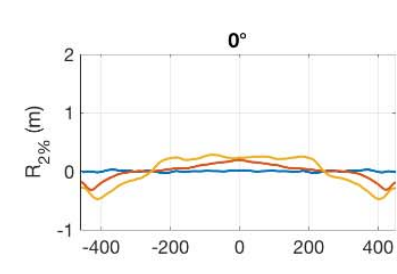

$0^{\circ}$
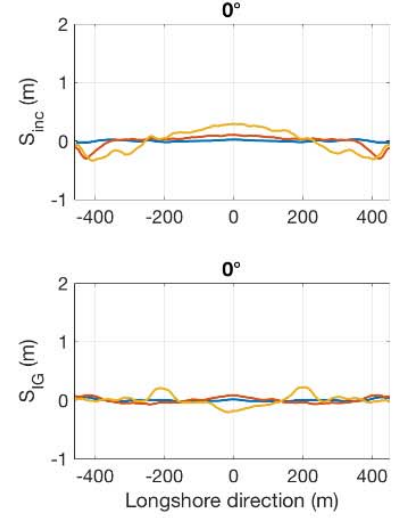

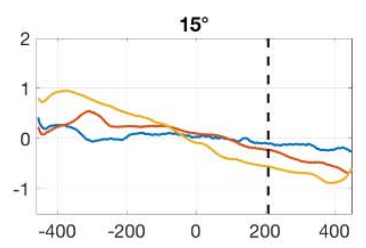

$15^{\circ}$

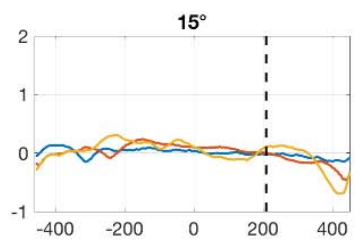

$15^{\circ}$

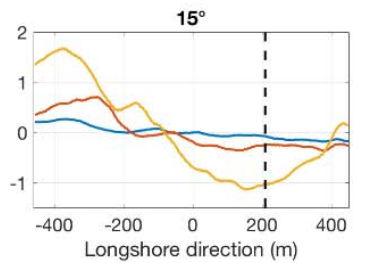

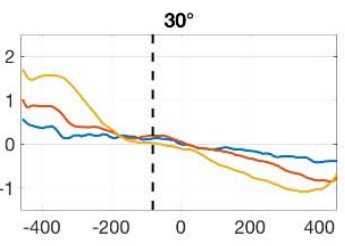
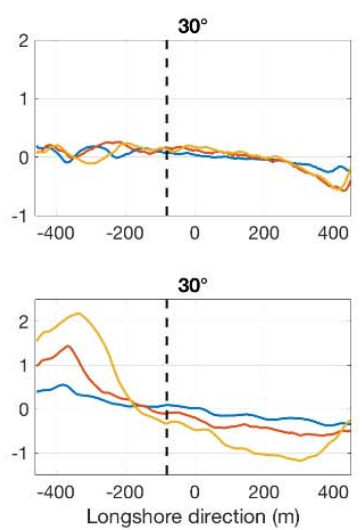

Figure 2. Longshore anomalies (difference between the local value and the mean longshore value) of $R_{2 \%}$, the significant swash height IG Sig and incident $S_{i n c .}$ Curve color: blue: moderate, red: high, yellow: storm, black dashed line: geometric shadow.

Figure 2 confirms that the wave angle induces a substantial anomaly in the run-up distribution. For the most energetic case, the anomaly can be well over 1 meter. As expected, in the shadow zone (right side of the black dashed lines), sheltered from the incident waves by the headland, the run-up anomaly is negative, meaning the values in this area are smaller than the mean value. Outside the shadow zone the run-up gradually 


\section{XVIèmes Journées Nationales Génie Côtier - Génie Civil \\ Le Havre 2020}

increases to a point of locally high values, in the area exposed to direct swell, close to the opposed headland. It appears that the headland plays a crucial role in focusing the energy leading to a high run-up.

\subsection{Contributions of incident and infragravity bands}

Figure 3 shows the distribution of the ratio $\mathrm{S}_{\mathrm{ig}} / \mathrm{S}_{\mathrm{inc}}$ along the beach. For all wave conditions in the case of a normal incident swell the swash motions are IG dominated $\left(\mathrm{S}_{\mathrm{ig}} / \mathrm{S}_{\mathrm{inc}}>1\right)$. For the most energetic conditions, the IG domination is stronger than for the two other cases, which is expected as the conditions are more dissipative. When the swell is approaching the embayed beach with an angle, the contributions of incident and IGwaves vary along the beach, meaning that the energy is redistributed spatially and also in the frequency domain. In the exposed zone, a clear increase of the IG energy is noticeable. The swash motions in all cases become strongly IG-dominated, with values of $\mathrm{S}_{\mathrm{ig}} / \mathrm{S}_{\mathrm{inc}}$ higher than 1.5. This means that during a single event, sections of the beach can behave as dissipative, intermediate or reflective.
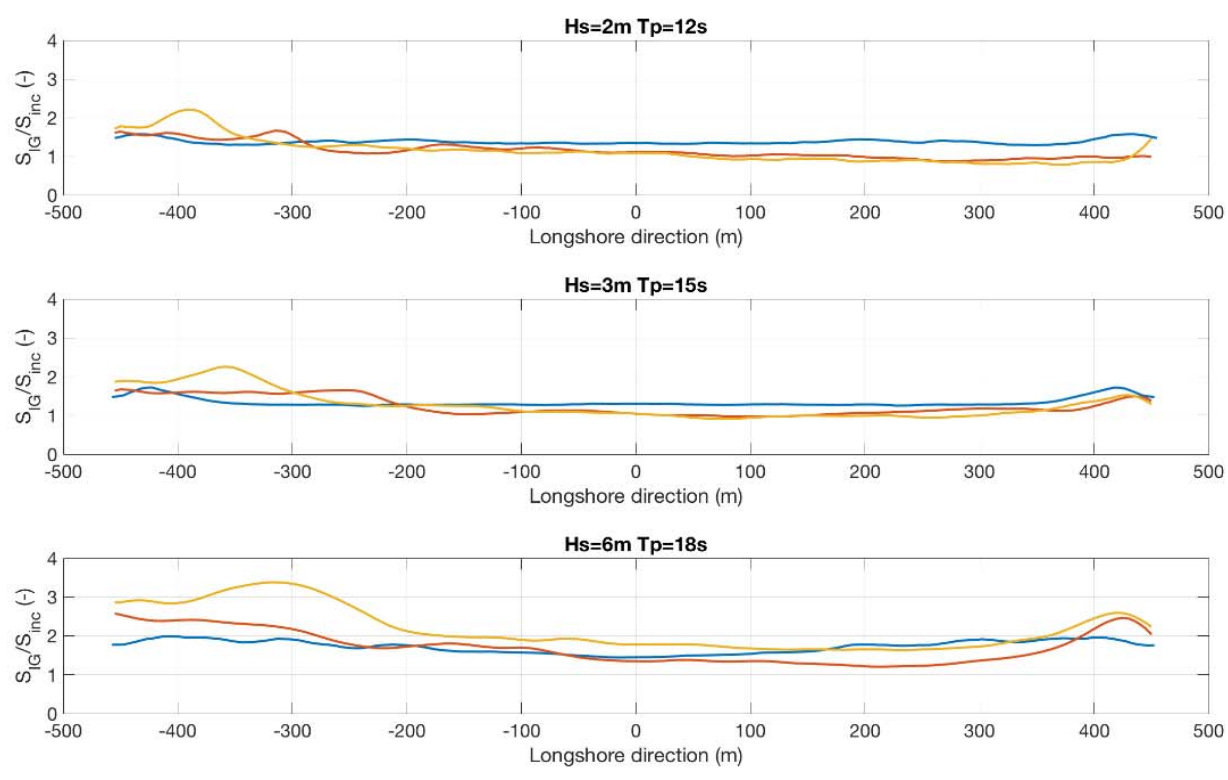

Figure 3. Longshore evolution of the ratio $S_{i g}$ over $S_{\text {inc }}$ for the different conditions. Curve color: blue: $0^{\circ}$, red: $15^{\circ}$, yellow: $30^{\circ}$.

Usually the beach state is given globally for a beach depending on the foreshore slope and offshore conditions (Iribarren number). However, in this configuration a different parametrization should be used to accurately define the beach state.

The different processes (diffraction, reflection) could contribute to the uneven longshore 


\section{Thème 1 - Hydrodynamique côtière}

distribution of the wave height and therefore impact the wave breaking. As a primary mechanism of energy dissipation and transfer, the distribution of the wave breaking is closely related to the one of the run-up and needs to be further investigated.

\section{Conclusions}

In this study, the variability of the run-up along an idealized simplified embayed beach was addressed based on the results of a phase-resolving model for different incident wave conditions and bay orientation. The results show that the run-up can vary significantly along this idealized beach, with alongshore hotspots where run-up values can be amplified by a factor of over 1.5 compared to the mean longshore value. As expected, under oblique incident wave conditions the mean longshore $R_{2} \%$ values are smaller due to increasing sheltering effect of the headlands, however this is also when the highest values of $R_{2} \%$ are observed. This study also highlights that the longshore variability of the run-up is essentially controlled by the variability of energy in the IG band. This result suggests that the consideration of IG waves might be critical to correctly address run-up characteristics in an embayed beach including their uneven contribution along the beach, which can vary according to incident wave conditions. This should be confirmed under more realistic beach configurations.

\section{References}

BATTJES J.A. (1974). Surf similarity. Proceedings 14th International Conference on Coastal Engineering, pp 466-480. https://doi.org/10.9753/icce.v14.26

CASTELlE B., COCO G. (2012). The morphodynamics of rip channels on embayed beaches, Continental Shelf Research, Vol. 43, pp 10-23. https://doi.org/10.1016/i.csr.2012.04.010 DEAN R.G. (1991). Equilibrium beach profiles: characteristics and applications. Journal of Coastal Research, Vol.7, pp 53-84.

FELLOWES T.E., VILA-CONCEJO A., GALLOP S.K. (2019). Morphometric classification of swell-dominated embayed beaches, Marine Geology, Vol. 411, pp 78-87. https://doi.org/10.1016/j.margeo.2019.02.004

GODA Y., TAKAYAMA T., SUZUKI Y. (1978). Diffraction diagrams for directional random waves. 16th International Conference on Coastal Engineering. https://doi.org/10.1061/9780872621909.037

HOLMAN R. (1986). Extreme value statistics for wave run-up on a natural beach. Coastal Engineering. Vol. 9(6), pp 527-544. https://doi.org/10.1016/0378-3839(86)90002-5 HOLMAN R.A., SALLENGER A.H. (1986). Longshore variability of wave run-up on natural beaches. $19^{\text {th }}$ International Conference on Coastal Engineering, pp 1896-1912. https://doi.org/10.1061/9780872624382.128

HORRILlO J., GRILlI S.T., NICOLSKY D., ROEBER V., ZHANG J. (2014). Performance benchmarking tsunami models for NTHMP's Inundation mapping activities. Pure Appl. Geophys. Vol. 172, pp 869-884. https://doi.org/10.1007/s00024-014-0891-y 


\section{XVIèmes Journées Nationales Génie Côtier - Génie Civil \\ Le Havre 2020}

LOUREIRO C., FERREIRA Ó., COOPER J.A.G. (2012). Geologically constrained morphological variability and boundary effects on embayed beaches. Mar. Geol., Vol. 329, pp 1-15. https://doi.org/10.1016/j.margeo.2012.09.010

LYNETT P.J., ROEBER V., HEITMANN T.W., CHEUNG K.F., DAVID C.G. BRIKER J.D. et al. (2017). Inter-model analysis of tsunami-induced coastal currents. Ocean Modelling, Vol. 114, pp 14-32. https://doi.org/10.1016/j.ocemod.2017.04.003

NWOGU O. (1993). Alternative form of Boussinesq equations for nearshore wave propagation. Journal of Waterway, Port, Coastal and Ocean Engineering, Vol. 119. https://doi.org/10.1061/(ASCE)0733-950X(1993)119:6(618)

POWER H., ATKINSON A., HAMMOND T., BALDOCK T. (2013). Accuracy of wave runup formula on contrasting southeast Australian beaches. Coasts and Ports 2013, $21^{\text {st }}$ Australasian Coastal and Ocean Eng. Conf. \& $14^{\text {th }}$ Australasian Port and Harbor Conf., $6 \mathrm{p}$.

ROEBER V., CHEUNG K.F., KOBAYASHI M.H. (2010). Shock-capturing Boussinesqtype model for nearshore wave processes. Coastal Engineering, Vol. 57(4), pp 407-423. https://doi.org/10.1016/j.coastaleng.2009.11.007

ROEBER V., CHEUNG K.F. (2012a). Boussinesq-type model for energetic breaking waves in fringing reef environments. Coastal Engineering. Vol. 70, pp 1-20. https://doi.org/10.1016/j.coastaleng.2012.06.001

ROEBER V., CHEUNG K.F. (2012b). BOSZ - Boussinesq Ocean and Surf Zone model. NOAA, Special Report, Proceedings and Results of the 2011 NTHMP Model Benchmarking Workshop, Galveston, Texas, 437 p.

RUESSINK B.G., KLEINHANS M.G., VAN DEN BEUKEL P.G.L. (1998). Observations of swash under highly dissipative conditions. J. Geophys. Res., Vol. 103, pp 3111-3118. https://doi.org/10.1029/97JC02791

RUGGIERO P., HOLMAN R.A., BEACH R.A. (2004). Wave run-up on a high-energy dissipative beach. J. Geophys. Res. 109, C06025. https://doi.org/10.1029/2003JC002160

SHEREMET A., KAIHATU J.M., SU S.-F., SMITH E.R., SMITH J.M. (2011). Modeling of nonlinear wave propagation over fringing reef. Coastal Engineering, Vol. 58, pp 1125-1137. https://doi.org/10.1016/j.coastaleng.2011.06.007

STOCKDON H., HOLMAN R., HOWD P., SALLENGER A. (2006). Empirical parameterization of setup, swash, and runup. Coastal Engineering. Vol. 53(7), pp 573-588. https://doi.org/10.1016/i.coastaleng.2005.12.005

STOCKDON H., THOMPSON D., PLANT N., LONG J. (2014). Evaluation of wave runup predictions from numerical and parametric models. Coastal Engineering. Vol. 92, pp 1-11. https://doi.org/10.1016/j.coastaleng.2014.06.004 
Thème 1 - Hydrodynamique côtière 